\title{
PReS-FINAL-2330: Canakinumab treatment in patients with HIDS
}

\author{
J Antón ${ }^{1 *}$, I Calvo ${ }^{2}$, A Robles ${ }^{3}$, J Yagüe ${ }^{4}$, J Aróstegui ${ }^{4}$, R Viana ${ }^{5}$, S Bhansalii, K Abrams ${ }^{6}$ \\ From 20th Pediatric Rheumatology European Society (PReS) Congress \\ Ljubljana, Slovenia. 25-29 September 2013
}

\section{Introduction}

Hyper-IgD and periodic-fever syndrome (HIDS) is a recessively inherited-autoinflammatory condition caused by mevalonate-kinase mutations. It is characterized by early-onset ( $<1$ year of age), 4- 6 days-long acute inflammatory episodes that typically recur every 4-6 weeks. The main features during episodes include fever, lymphadenopathies, rash, headache, abdominal pain, diarrhea, and a marked acute phase reaction[1,2]. Previous case reports suggested IL-blockade as a potential therapy. Canakinumab (CAN) is a fully-human, selective anti-IL-1 $\beta$ monoclonal-antibody (MoAb). Preliminary clinical and pharmacokinetics (PK) data of CAN-therapy in active HIDS patients is presented.

\section{Objectives}

Primary objective was to assess if CAN reduces the flarerate during the treatment period (TP) compared with that from the historical period (HP). One secondary objective was to assess the PK and pharmacodynamics of CAN.

\section{Methods}

This is a 6-month open-label CAN TP and a follow-up period lasting until relapse or up to 6-months max. Patients $\geq 2$ years-old with active HIDS, CRP $>10 \mathrm{mg} /$ $\mathrm{L}$, and $\geq 3$ febrile acute-flares in a 6 -month HP were included. All received CAN $4 \mathrm{mg} / \mathrm{kg}$ (max. $300 \mathrm{mg}$ ) Q6-weeks in TP, with only one dose up-titration to 6 $\mathrm{mg} / \mathrm{kg}$ (max. $450 \mathrm{mg}$ ) if a flare occurred during the first 6 -weeks.CAN concentrations were determined by ELISA from samples collected at pre-dose, at prespecified time points during the first-month, and at flares. Population PK analysis was performed using NONMEM $^{\circledR}$-program.

${ }^{1} \mathrm{H}$. Sant Joan de Déu, Barcelona, Spain

Full list of author information is available at the end of the article

\section{Results}

Nine patients $(6 \mathrm{~F}, 3 \mathrm{M})$ with a median age of 17.3 years (5-29 years) were enrolled. The median number of flares/patient reduced from 5(3-12) during the HP to 0 (0-2) during the TP. Two patients had a total of 3 flares during the TP and both required dose up-titrated, with no flares afterwards during the TP. Seven out of 9 patients flared during the follow-up period at a median of 110 days (62-196) after the last CAN dose. Population PK analysis showed that serum clearance of CAN and its volume of distribution were dependent on bodyweight. The estimated apparent serum clearance (CL/F) of CAN was $0.20 \pm 0.041 \mathrm{~L} /$ day and the corresponding volume of distribution $\left(\mathrm{V}_{\mathrm{ss}} / \mathrm{F}\right)$ was $11.6 \mathrm{~L}$. Following the first dose, the mean (SD) observed $\mathrm{C}_{\max }$ was $30.4 \pm 8.13$ $\mu \mathrm{g} / \mathrm{mL}$. Apparently weight normalized PK parameters were similar to those observed in other diseases. Adverse events (AE) were reported in eight patients, most were mild (76\%) or moderate $(18 \%)$, and none led to CAN discontinuation. Infections, mostly involving the respiratory tract, were the most common type of $\mathrm{AE}$ reported. Two patients reported a serious AE (1 HIDS flare hospitalization, and 1 gastrointestinal infection bleed and separate peritonitis).

\section{Conclusion}

In this small study, CAN decreased the flare-rate substantially. PK of CAN in HIDS patients was as expected for a MoAb and the weight normalized PK parameters were comparable to those observed in other patient populations. The AEs reported were manageable. Further study is needed to better define CAN treatment in HIDS.

\section{Disclosure of interest}

J. Antón: None Declared, I. Calvo: None Declared, A. Robles: None Declared, J. Yagüe: None Declared, 
J. Aróstegui: None Declared, R. Viana Employee of: Novartis Farmacéutica, S.A., S. Bhansali Employee of: Novartis Pharmaceuticals Corp, USA, K. Abrams Employee of: Novartis Pharmaceuticals Corp, USA.

\section{Authors' details}

${ }^{1} \mathrm{H}$. Sant Joan de Déu, Barcelona, Spain. ${ }^{2} \mathrm{H}$. La Fe, Valencia, Spain. ${ }^{3} \mathrm{H}$. La Paz, Madrid, Spain. ${ }^{4} \mathrm{H}$. Clínic i provincial de Barcelona, Spain. ${ }^{5}$ Novartis

Farmacéutica, S.A., Barcelona, Spain. 'Novartis Pharmaceuticals Corp,

Hanover, USA.

Published: 5 December 2013

\section{References}

1. Drenth JP, et al: N Engl J Med 2001, 345:1748-57.

2. Van der Hilst JC, et al: Medicine (Baltimore) 2008, 87:301-10.

doi:10.1186/1546-0096-11-S2-P320

Cite this article as: Antón et al:: PReS-FINAL-2330: Canakinumab

treatment in patients with HIDS. Pediatric Rheumatology 2013 11(Suppl 2): P320.

Submit your next manuscript to BioMed Central and take full advantage of:

- Convenient online submission

- Thorough peer review

- No space constraints or color figure charges

- Immediate publication on acceptance

- Inclusion in PubMed, CAS, Scopus and Google Scholar

- Research which is freely available for redistribution

Submit your manuscript at www.biomedcentral.com/submit 